Zagadnienia Rodzajów Literackich, LX, z. 3

PL ISSN 0084-4446

DOI: $10.26485 / Z R L / 2017 / 60.3 / 2$

LUKASZ BoguCKI

Uniwersytet Łódzki*

\title{
The Terminological Conundrum of Translation Studies. Toward a Polish Dictionary of Translation Terms
}

\begin{abstract}
The aims of this paper are as follows: to provide an outlook on the current state of Translation Studies as an academic discipline, including literary and non-literary approaches; to advocate the need for a terminological revision and up-to-date taxonomisation within Translation Studies, in Polish, English, as well as other major European languages; to describe an ongoing project that may eventually be a small step toward accomplishing the above.
\end{abstract}


* Instytut Anglistyki Uniwersytetu Lódzkiego ul. Pomorska 171/173, 90-236 Lódź e-mail: lukasz.bogucki@gmail.com 


\section{Translation Studies as we know it}

It is neither an easy task nor, in fact, is it the aim of this paper to establish a precise timeline for Translation Studies ${ }^{1}$. However, in order to position it in the broad context of the humanities and to understand its relationship with linguistics and literary studies, an attempt must be made to gauge the temporal context of the transition from published comments on translating and translations to works laying the theoretical foundations of the budding discipline.

Understood (however flawed this definition may be) as the process of producing a target language equivalent of a source language text, translation has existed far longer than any theoretical attempts at comprehending its nature. Some like to call it "the second oldest profession in the world", leaving the presupposition as to what the first one may be hanging in the air. If this were true, there would be only one human need more basic than communication, though the latter is rather conspicuous by its absence from Maslov's seminal hierarchy.

Systemic academic writing on translation (not to be confused with prescriptive handbooks for translators) commenced in the late 1950s (Jakobson 1958; Vinay and Darbelnet 1958). As such, these models were heavily influenced by structuralist linguistics.

A universal cornerstone in academic writing on translation is Eugene A. Nida's (1964) seminal text, despite frowns from Polish scholars, who would have preferred it to be Olgierd Wojtasiewicz's (1957) introductory textbook, had it been written in a more widespread language than our own. Nida's book is also evidence for the irreconcilable duality of Translation Studies. His model of the translation process, though exemplified by passages from the Bible, was a direct application of Noam Chomsky's transformational generative grammar. Therefore, most writing on translation in the 1960s and early 1970s was rooted in linguistics. The title of another seminal publication by J. C. Catford (1965) firmly positions translation within the realm of applied linguistics.

1 When capitalised, the term "Translation Studies" may be used as a shortened version of "Descriptive Translation Studies", to refer to a seminal, literary-centred approach that revolutionised translation theory in the 1980s (cf. Toury 1995 and elsewhere). Here, however, it is used to mean the discipline interested in researching translation. 
At the same time, in another corner of the world, the poet James S. Holmes began working at the Department of Translation Studies of the University of Amsterdam, and soon (Holmes 1972) created the foundation of what later (Toury 1995) became a map of the discipline. Translation Studies (note the plural, see also below) officially started bifurcating. It is evident for any translator, scholar or trainee that the target readership, skopos or quality assessment of literary translation differs from that of specialised translation, which is in turn different from that of audiovisual translation. However, the situation where linguistic and literary approaches to (the theory of) translation go their own separate ways and never meet is an undesirable one. Translation research has always been plagued by the divide between theory and practice: translators needing no theory to do their job and translation scholars locked away in their ivory towers. Sadly, it appears that the respective ivory towers are built either on linguistic or literary foundations, which further hampers the establishment of a conceptually and methodologically independent discipline.

Even a cursory sketch of the development of Translation Studies is far beyond the scope and limitations of this paper. I do not intend to go into the premises of the Leipzig school, the Manipulation School, the Interpretive Theory of Translation, postcolonial or feminist theories of translation, or the cultural turn. These seminal approaches have received ample treatment in literature over the years (cf. Munday 2001 for a comprehensive review). My interest herein lies in what Translation Studies is now and why. Let us compare two facts. In 1958, participants of the International Congress of Slavists agreed that it was time for translation to go its own separate way, rather than be an integral part of either literary studies or linguistics (Cary 1959), so that workshops of translation like those offered at the time by departments of Comparative Literature at Princeton or the University of Iowa could be taught as part of an independent discipline. In 2017, the discipline is still suffering from an identity crisis, as for example research centres in Translation Studies in the UK may still be coordinated by professors of Comparative Literature $^{2}$. Translation Studies is now a major force in academia, yet its proponents may still be doctors and professors of linguistics or literature, translation scholars sensu lato rather than sensu stricto. This is no criticism against literary studies or linguistics whatsoever; this is a call for a formal recognition of the academic discipline that explains the process of cross-cultural communication.

In her outline of Translation Studies in the last 60 years, Teresa Tomaszkiewicz claims that a central notion among the array of theoretical approaches and models is the translator:

Researchers strive to analyse the process taking place in the translator's mind by examining its complexity from the point of view of translation strategies, challenges, and methods. There are numerous studies on the place and role of the translator on the current job market. New research avenues concern the translator's emotional intelligence, stress management, customer relations, the translator's workplace, etc. (Tomaszkiewicz 2016: 52; translation mine)

While the translator can indeed be the focal point unifying methodologically and theoretically diverse approaches to translation, the pertinent question remains: what makes (or perhaps who makes) the translator? There are three factors that distinguish excellent translators from mediocre ones: aptitude (including language competence, concomitant

2 I am indebted to Dr Federico Federici of University College London for providing this information. 
with translation competence), training, and expertise. Assuming that the second and the third factors do not merge, but rather follow one another in a consecutive fashion, training takes place in academia and expertise is gained later, in the world of work. Poland is one of many places where translation can be studied only at language departments, with very few exceptions (see Bogucki 2016 for a more detailed discussion). Instructors are sourced from among academic staff, who have degrees either in linguistics or in literature (again, with very few exceptions). Thus, the trainee is coached by a linguist, a poet, a writer, a literary critic etc.; the split between literary translation and specialised translation deepens to an irreparable extent, and translation (and by extension Translation Studies) becomes fossilised in mechanisms and methodologies specific to language and literature respectively.

The adjective "interdisciplinary" is commonly attached to the name of the discipline (see e.g. Wilss 1999). However, it has become a buzzword in modern academic discourse, too often merely a cover for a lack of shape and substance. Tomaszkiewicz (2016: 57) points to the plural in Translation Studies. Out of several Polish equivalents for the name of the discipline, the prevalent one appears to be "przekładoznawstwo", a singular noun. Perhaps a plural Polish term would better reflect the nature of the discipline, or perhaps more than one term is necessary. Such dilemmas will hopefully be answered with the help of the project described later in the text.

\section{Translation Studies in the Information Age - a plea for revision and consolidation}

It has been 45 years since the conception and 22 years since the visualisation of the map of Translation Studies (see above); 29 years ago, Mary Snell-Hornby (1988) attempted to integrate all translation into a single, one-page diagram. Today, these seminal approaches are still referenced in the literature, but they can no longer serve as cornerstones for understanding the nature of translation, as they fail to account for modern developments in the discipline. Even if one ignores all the pertinent changes in the process of translation, translation competence, criteria for quality assessment, or translator training, the classical taxonomy of literary, specialised and general translation is no longer adequate. A comprehensive, convincing, expert-level discussion on the position of audiovisual translation, localisation, and interpreting, including the place of theories thereof within Translation Studies as such, is in order.

The most influential and frequently used reference works on translation theory include Shuttleworth and Cowie 1997 and Baker 1998. The Polish terminology of Translation Studies was first compiled in Lukszyn 1991 and 1993. An encyclopedic work was published at the turn of the century (Dambska-Prokop 2000). A few years later, the Polish version of a popular reference work commissioned by the prestigious association CIUTI was compiled (Delisle, Lee-Jahnke, and Cormier 2004, translated into Polish by Teresa Tomaszkiewicz).

A mere glance at the dates shows that Translation Studies terminology has not been regularly updated and categorised (apart from a revised edition of Dąmbska-Prokop's encyclopedia, published in 2010). New phenomena such as crowdsourcing or translation technologies are essentially missing from reference works. The latter in particular are a major issue, as translation aids change practically on a yearly basis; a book that I wrote on computer-assisted translation (Bogucki 2009) is now little more than a museum piece, as eight years ago translation technologies were at a quite different stage of refinement. 
The implications are threefold. Firstly, new terms are used intuitively, never being properly defined by lexicographers. Moreover, terms proliferate, resulting in an undesirable lack of terminological consistency; to use the example above, crowdsourcing, collaborative translation, volunteer translation, amateur translation, or Wiki-translation all refer to similar phenomena, therefore lexicographic work would be in order, so as to delineate the scope of each term and perhaps discard some of the less frequently used or more repetitive ones. Similarly, audiovisual translation (AVT) appears to be the generally accepted nomenclature for the (relatively) new genre within Translation Studies, while screen translation, multimedia translation, constrained translation, language transfer, or versioning now have either purely historical import, or denote other, unrelated translation types/phenomena. Thirdly, there may be no universally acknowledged equivalents of these new terms in minority languages; as a result, the least-effort translation procedure — borrowing — is deployed, producing scholarly works in languages such as Polish that are cluttered with English terminology.

The rationale behind the dictionary project described in the next section grew simultaneously with the plea for recognition of Translation Studies as a university discipline in Poland. Scholarly interest in translation has been constantly increasing ever since the subject was introduced into philological curricula (which, in the case of the University of Lódź, took place in the late 1980s). Out of the 20 Polish universities where foreign languages can be studied ${ }^{3}$, all teach translation and most offer electives in translation theory. The interest does not stop at the deluge of B.A. and M.A. dissertations either. Numerous monographs submitted in partial fulfilment of the requirements for the highest academic degree in Poland (babilitation) and for the professor ordinarius title are topically and methodologically translational, that is to say they can be considered as belonging to the literature on the subject of translation/Translation Studies, and are in fact listed as such ${ }^{4}$. However, by and large they will have either a linguistic or a literary bias. The excellent anthology of Polish translational thought (Heydel and Bukowski 2013), as well as its predecessor, another collection edited by the same Polish scholars, but scrutinising works of international translation scholars (Bukowski and Heydel 2009), strive for representativeness, but due to both editors' background and predilection, cannot help leaning somewhat toward literary approaches to translation (or approaches to literary translation).

However, reviewers of translational publications submitted for degrees in literature or linguistics (as it is formally impossible to receive a degree in Translation Studies in Poland) increasingly notice that these publications are firmly rooted in the methodology and background literature of Translation Studies and concern strictly translation-related phenomena, therefore conferment of a degree in literature or linguistics on such a basis is an unfortunate necessity ${ }^{5}$. These candidates would certainly be better served if they could formally apply for a degree in Translation Studies. To that end, motions to the Ministry

3 This includes all the main state universities, excluding Cardinal Stefan Wyszyński University in Warsaw, plus SWPS University of Social Sciences and Humanities in Warsaw, The John Paul II Catholic University of Lublin, and Siedlce University of Natural Sciences and Humanities.

4 Cf. BITRA, Bibliography of Interpreting and Translation, available online at dti.ua.es/en/bitra/introduction.html

5 cf. e.g. the reviews of the habilitation procedure of Agnieszka Szarkowska (in Polish), available online at http://www.ck.gov.pl/promotion/id/6174/type/l.html 
of Higher Education have been submitted, thus far to no avail (see also Bogucki 2016). It is argued that inevitable overlapping between disciplines necessitates a new taxonomy, as the problem concerns other disciplines within the humanities and extends to social and exact sciences.

Literature on translation highlights its paramount role in human communication. The title of a recent monograph (Blumczyński 2016) aptly uses the adjective "ubiquitous" to account for the author's research assumption that translation is in fact everything and everywhere. Yet this cornerstone of communication since the Tower of Babel fails to be officially recognised as a discipline in its own right not only in Poland.

The second decade of the $21^{\text {st }}$ century is witnessing a surge of interest in methodological aspects of Translation Studies (cf. Saldanha and O’Brien 2013). Translational methodologies draw heavily on linguistics and literary studies, but methodological tools are rarely confined to a single discipline, triangulation is a common phenomenon (cf. Cohen and Manion 2000: 254), and the most common quantitative and qualitative methods (questionnaire and interview, respectively) are widely used within and outside the humanities. There seems to be significant potential behind utilising high-tech tools hitherto underused in research within the humanities, such as eye-tracking (Göpferich, Jakobsen, and Mees 2008). It is hoped that refining the methodology for Translation Studies can go a long way toward revising and unifying the discipline.

\section{A dictionary in the making}

In early 2016, I assembled a team of 18 Polish academics ${ }^{6}$ representing 8 Polish higher education institutions (predominantly universities), who are internationally known for their research in translation, though their degrees are officially in linguistics or literature. My aim was to consolidate the Polish Translation Studies community by collaborating to produce a reference work for translation theorists, scholars, and students. The team members work at departments/institutes/faculties of: Polish, English, German, Italian, French, and Russian. Currently no Spanish philologist is on board, but due to the worldwide impact of the language, plans to add Spanish equivalents for the entries are underway. Shortlisting languages for a multilingual terminological dictionary is always a compromise, and decisions are taken on the basis of availability of resources (human or otherwise) as well as projected target audience and purpose (or skopos, to use a translation term); however, it is felt that the seven languages (with Polish in the foreground) are representative of the linguistic distribution of European writing on translation and the authors' goals in compiling the reference work. An international advisory board is being assembled to supervise work on providing the foreign language equivalents; additionally, four of the team's members are eminent scholars with ample expertise in lexicographic work (three of them are Professors Emeritus), all authors or editors of current reference works for Polish translation teachers and students, whose role is consultative in character.

During a terminological seminar in Kraków on October 21 ${ }^{\text {st }}, 2016$, under the auspices of the Consortium for Translation Education Research, the following semantic fields were agreed upon, in no particular order:

632 scholars have been invited altogether; however, 10 have had to withdraw due to other commitments, whereas 4 will join later as consultants. 
- adaptation

- prose translation

- poetry translation

- translation of religious texts

- translating children's literature

- theatre translation

- court interpreting

- conference interpreting

- technical translation

- translation of economic texts

- legal translation

- medical translation

- teaching translation and training translators

- audiovisual translation

- accessibility

- machine translation

- computer assisted translation

- $\quad$ sign language interpreting

- translatability and untranslatability

- methods, strategies, procedures, and techniques of translation

- equivalence

- crowdsourcing

- professionalisation

- Skopos Theory

- Relevance Theory

- history of translation

- metaphor in translation

- norms in translation

- Polysystem Theory

- intersemiotic translation

- pragmatics in translation

- cognitive theory of translation

- translation of music

- certified/sworn translation. 
The above is a purely practical arrangement. The dictionary is not intended to be a thesaurus; the fields have been generated merely for the purpose of division of labour, as each member of the team works on one or more fields. Overlapping is inevitable, but should the same term be generated by more than one of the team's lexicographers, a decision will have to be made as to whether to qualify it as an error, or perhaps a polysemous entry, necessitating a definition of two or more senses. This categorisation may be controversial due to fuzzy boundaries between the fields, their respective volume measured by the total number of potential entries for each, as well as varying theoretical import (there are translation types, translation problems, approaches, models, and methods). However, the resulting aggregate is hoped to be an exhaustive representation of current translation terminology.

A vexing question, typical for any specialised dictionary/glossary/lexicon, is which terms are specialised enough to qualify; in other words, what makes a term a Translation Studies term? Arguably, such entries as "author", "self-concept", "management skills", or — interestingly — "finger" (for sign language interpreting), are not salient translation terms, though they are already in the database. Some terms are strictly linguistic, e.g. "Speech Acts Theory", others belong in the area of literary interpretation ("paratext"). There are terms positioned on the fringes of the humanities, if not outside ("eye-tracking"). "Image" is a central concept in audiovisual translation research and as such can hardly be left out, but is it a translation term? Such dilemmas are not the preserve of this particular project, but rather part and parcel of compiling most dictionaries and encyclopedias of Translation Studies, due to its interdisciplinary nature.

Entries in the forthcoming dictionary will be between 100 and 300 words in length. References will be provided in the form of a collective bibliography. A sample entry will look as follows:

Translation procedure

cf. translation technique

1. the use of a particular solution to a translation problem at the level of translation unit. Translation procedures are micro-contextual and problem-centred. Procedural solutions are the translator's individual decisions concerning particular dilemmas in the process of translating, in line with the overall approach to the task at hand, or translation strategy. Translation as a decision-making process involves applying procedures as a result of the chosen strategy, depending on the specificity of the translation task, contextual determinants, source text priorities, and skopos.

The notion of translation procedure is particularly common in functionalist approaches to translation.

Examples of translation procedures (translation techniques) include borrowing, explicitation, transposition, and transliteration.

2. the result of a translator's decision concerning a particular translation problem.

3. [in psycholinguistic approaches to translation] the equivalent of translation strategy, a translator's way of solving a translation dilemma in the process of translation.

Each entry will be formulated in Polish, but will come with equivalent terms in English, French, Spanish, German, Russian, and Italian. 
Currently there are approximately six hundred terms in the database, which is growing on a daily basis. As indicated elsewhere, the main language is Polish. However, on occasions, authors are finding it difficult to provide entries for foreign language terms that they know and use regularly in their research. Examples include "cognitive debriefing", "embodied translation", "volunteer translation", "intra-rater reliability", "inter-grader triangulation", 'narrowcasting", "peer-tutoring", "socio-cognitive apprenticeship", "visually salient item", and more. While terminology as a discipline recognises borrowing and loan translation as common procedures in specialised language, purists will insist on avoiding excessive use of these when a neologism in the target language can be created instead (and ideally used thereafter as the only term for the given designate). The team will therefore have to propose hitherto absent equivalents and recommend that they be used in relevant literature; such was the case of "przekład kolaboratywny" ("collaborative translation"), which is being proposed in the Polish literature on amateur translation (cf. LewandowskaTomaszczyk 2015).

Additionally, terminological inconsistency may pose a threat. Assuming that much Polish Translation Studies terminology is borrowed or translated from English, more than one Polish equivalent may be in use. A key term pertaining to a strategy of (literary) translation, conceived by Schleiermacher and refined by Venuti (1998), is foreignisation. In Tomaszkiewicz's translation of the CIUTI dictionary (Delisle, Lee-Jahnke, and Cormier 2006) and elsewhere in numerous Polish publications on the theory of literary translation, the equivalent "udomowienie" is used; however, "forenizacja" enjoys an almost equal status (cf. Bukowski and Heydel 2009). One of the aims of the project under scrutiny is to achieve the terminological optimum of one equivalent per one term. This can be accomplished by means of arbitrary decisions of the team members as experts in the field, supported by corpus work on frequency of usage in translation literature. However, this lexicographic optimum may be initially hard to achieve in some cases, due to polysemy and different understanding of the same term by translation scholars from literary vs. linguistic backgrounds. The team comprises both linguistic and literary minds, in the hope of terminological reconciliation; while the independent status of literary studies and linguistics cannot be undermined in this work, a common methodological and conceptual ground can certainly be found.

On top of translation terms as entries, the dictionary will contain three appendixes: (a) a list of Polish translation scholars together with biodata; (b) an inventory of Polish translation associations, and c. a catalogue of Polish translation journals.

\section{Conclusions}

The dictionary is envisaged to come out both in electronic and traditional form in 2018 or 2019. What may be its foreseen impact outside Poland? The indexes of terms in six languages may serve as a useful inventory of current terminology of Translation Studies. A translation of the full text into Italian is planned after the original has been published; other languages may follow.

With over 68,000 publications listed in the BITRA database (cf. footnote 4 above), several series of conferences worldwide, international associations, and its obvious presence in academic curricula, the existence of Translation Studies cannot possibly be denied. 75,798 people have subscribed to the Translation Studies keyword on 
academia.edu ${ }^{7}$, which testifies to its popularity among scholars who are either digital natives or digital converts. However, the community service's competitor, researchgate.net ${ }^{8}$, lists Translation Studies under Linguistics and its subtype Applied Linguistics, which testifies to the prevalence of traditional taxonomies. The profile of a discipline in an online community service can be modified in a matter of seconds with a few clicks; changing a fossilised academic viewpoint takes considerably more effort.

The dictionary presented in this paper is neither intended nor hoped to revolutionise the way scholars (Polish or otherwise) look at translation and Translation Studies. However, it will certainly be another small step toward integrating the two communities of translation researchers, viz. literary- and linguistic-oriented, with a view to promoting an independent, fully-fledged discipline without an evident bias either way. Its complex character may be reflected in its plural name and the duality will certainly be visible in the topics of publications (literary and non-literary translation respectively), but a discipline in its own right, recognised by ministerial authorities, is an absolute necessity; a discipline not artificially severed from linguistics and literary studies, but interfacing with them for the sake of informed and comprehensive academic output.

\section{Bibliography}

Baker Mona, ed. (1998), Routledge Encyclopedia of Translation Studies, Routledge, London-New York.

Blumczyński Piotr (2016), Ubiquitous Translation, Routledge, London-New York.

Bogucki Łukasz (2009), Tłumaczenie wspomagane komputerowo, PWN, Warszawa.

- (2016), Norma a uzus w przektadzie audiowizualnym: ograniczenia a oczekiwania [in:] Norma a uzus w przekładzie tekstów specjalistycznych, eds A. Fimiak-Chwiłkowska, B. Walkiewicz, J. Woroch, Wydawnictwo Naukowe UAM, Poznań.

Bukowski Piotr, Heydel Magdalena (2009), Współczesne teorie przekładu. Antologia, Znak, Kraków.

Cary Edmond (1959), Andréi Fédorov. Introduction à la théorie de la traduction, „Babel 5”.

Catford John C. (1965), A Linguistic Theory of Translation: an Essay in Applied Linguistics, Oxford UP, Oxford.

Cohen Louis, Manion Lawrence (2000), Research Methods in Education, Routledge, London.

7 Accessed on February $18^{\text {th }}, 2017$.

8 Accessed on February $18^{\text {th }}, 2017$. 
Dąmbska-Prokop Urszula, ed. (2000), Mała encyklopedia præęeładoznawstwa, Educator, Częstochowa.

—, ed. (2010), Nowa encyklopedia pržekładoznawstwa, Wyższa Szkoła Umiejętności im. Stanisława Staszica, Kielce.

Delisle Jean, Lee-Jahnke Hannelore, Cormier Monique (ed.) (2006), Terminologia ttumaczenia, trans. Teresa Tomaszkiewicz, Wydawnictwo Naukowe UAM, Poznań.

Göpferich Susanne, Jakobsen Arnt, Mees Inger (eds) (2008), Looking at eyes: Eyetracking Studies of Reading and Translation Processing, Copenhagen Studies in Language 36, Samfundslitteratur, Copenhagen.

Heydel Magdalena, Bukowski Piotr (2013), Polska myśl przekładoznawcza. Antologia, Wydawnictwo UJ, Kraków.

Holmes James S. (1972), The Name and Nature of Translation Studies [in:] Translated! Papers on Literary Translations and Translation, ed. J.S. Holmes, Rodopi, Amsterdam-Atlanta.

Jakobson Roman (1958), Essais de linguistique générale, Editions de Minuit, Paris.

Lewandowska-Tomaszczyk Barbara (2015), Rozwój kolaboratywnej kompetencji ttumaczeniowej, plenary lecture at the conference Zbliżenia: jezylkoznawstwo, translatoryka, literaturoznawstwo, State University of Applied Sciences in Konin.

Lukszyn Jurij, ed. (1991), Stownik dydaktyczny terminologii translatorycznej, Wydawnictwo UW, Warszawa.

—, ed. (1993), Tezaurus terminologii translatorycznej, PWN, Warszawa.

Munday Jeremy (2001), Translation Studies. Theories and Applications, Routledge, London-New York.

Nida Eugene A. (1964), Toward a Science of Translating: With Special Reference to Principles and Procedures Involved in Bible Translating, E.J. Brill, Leiden.

Saldanha Gabriela, O’Brien Sharon (2013), Research Methods for Translation Studies, Routledge, London-New York.

Shuttleworth Mark, Cowie Moira (1997), Dictionary of Translation Studies, St. Jerome, Manchester.

Snell-Hornby Mary (1995), Translation Studies. An Integrated Approach, John Benjamins, Amsterdam-Philadelphia.

Tomaszkiewicz Teresa (2016), Coraz bardziej interdyscyplinarny charakter badan przektadoznawcsych, „Między oryginałem a przekładem”, R. XXII nr. 1 (31).

Toury Gideon (1995), Descriptive Translation Studies and Beyond, John Benjamins, AmsterdamPhiladelphia.

Wilss Wolfram (1999), Interdisciplinarity in Translation Studies, „Target 11:1”.

Wojtasiewicz Olgierd (1957), Wstę do teorii ttumaczenia, Translegis, Warszawa.

Venuti Lawrence (1995), The Translator's Invisibility: A History of Translation, Routledge, London-New York.

Vinay Jean, Darbelnet Jean-Paul (1958), Stylistique comparée du français et de l'anglais, Didier, Paris. 